\title{
Perancangan Aplikasi Wisata Halal Berbasis Android Menggunakan Metode Geolocation And Haversine Formula Menuju Jombang Halal Smart City
}

\author{
Chandra Sukma Anugrah \\ Universitas Pesantren Tinggi Darul Ulum \\ chandrasukma@ft.unipdu.ac.id \\ https://doi.org/10.21107/dinar.v5i2.5003
}

\begin{abstract}
ABSTRAK
Indonesia memiliki banyak destinasi wisata halal yang tersebar di selurub indonesia babkan indonesia menempati peringkat ke 2 destinasi wisata halal dunia. Ini merupakan potensi yang sangat besar untuk di kembangkan. Wisata halal memiliki cakupan yang lebih luas tidak hanya mendata tempat - tempat religi seperti makam walisongo yang selama ini telah di lakukan oleh para peziarah. Melainkan lebih mengedepankan aspek pelaku atau wisatawannya untuk memfasilitasi kebutuhan sesuai dengan adab islam misalkan penginapan, makanan kuliner dan masjid. Informasi ini di perlukan bagi para wisatawan muslim pada umumnya.

Penelitian ini berorientasi pada pembuatan perancangan aplikasi wisata halal berbasis android yang dapat memudabkan para wisatawan untuk mengakses informasi wisata halal. Metode yang di gunakan dalam penelitian ini adalah geolocation dan haversine formula. Metode ini merupakan metode yang biasanya di terapkan untuk Geographic Information System (GIS). Di gunakan untuk menghitung jarak lokasi pengguna sistem dengan jarak lokasi wisata balal dan mampu menunjukan jalur untuk menuju ke lokasi wisata. Teknologi pendataan informasi wisata halal menggunakan web service rest API with JSON sehingga bisa terintegrasi dengan sistem informasi pariwisata daerah milik dinas pariwisata. Dengan sistem yang terintegrasi diharapkan konsep Jombang Halal Smart City bisa terwujud sesuai dengan misi Kementrian Pariwisata Halal Tourism Indonesia.
\end{abstract}

Kata kunci : Jombang, Halal Smart City, Geographic Information System (GIS), pariwisata 


\section{PENDAHULUAN}

Halal adalah sebuah konsep aturan prinsip agama Islam, yang digunakan untuk menyatakan suatu larangan untuk dikonsumsi oleh Muslim dengan dasar dari AlQur'an, hadist, atau ijtihad (kesepakatan ulama). Konsep halal diberikan apresiasi yang tinggi karena produk halal dianggap sebagai produk yang lebih sehat, lebih bersih, dan lebih lezat (Salindal, 2019). Indonesia menduduki peringkat ke 2 Pariwisata halal dunia. Dari data Global Muslim Travel Index (GMTI) 2018:

Tabel 1

\section{Peringkat Wisata Halal Indonesia}

\begin{tabular}{|c|c|}
\hline PERINGKAT & NEGARA \\
\hline 1 & Malaysia \\
\hline $\mathbf{2}$ & Indonesia \\
\hline 3 & Turki \\
\hline 4 & Arab Saudi \\
\hline 5 & Singapore \\
\hline 6 & Qatar \\
\hline 7 & Bahrain \\
\hline 8 & Omah \\
\hline 9 & Maroko \\
\hline
\end{tabular}

Pengembangan wisata halal penting karena manfaatnya tidak hanya dapat dirasakan oleh wisatawan Muslim. Wisata halal bersifat terbuka untuk semua orang. Kemenpar akan menggerakkan wisata halal di hotel, restoran, serta Spa. Diharapkan wisata halal dapat menjadikan Indonesia sebagai destinasi yang ramah untuk wisatawan Muslim dan memerlukan standarisasi. Ciri wisata halal antara lain ada paket-paket wisata halal yang meliputi destinasi ramah wisatawan Muslim, serta hotel, restoran, dan Spa yang halal.

Wisata Halal merupakan salah satu bentuk wisata berbasis budaya yang mengedepankan nilai-nilai dan norma Syariat Islam sebagai landasan dasarnya. Sebagai konsep baru didalam industri pariwisata tentunya wisata syariah memerlukan pengembangan lebih lanjut serta pemahaman yang lebih komprehensif terkait kolaborasi nilai-nilai keIslaman yang disematkan didalam kegiatan pariwisata. Wisatawan Muslim merupakan jumlah wisatawan terbesar di Indonesia yang notabene merupakan negara dengan populasi Muslim terbesar di dunia, konsep wisata Syariah merupakan jawaban akan besarnya untapped market yang belum tersentuh dengan maksimal. Dengan jumlah penduduk Muslim terbesar di dunia maka Indonesia merupakan pasar industri wisata Syariah terbesar di dunia dan sudah seharunya hal ini disadari oleh pelaku bisnis pariwisata di Indonesia hal ini dikarenakan pengembangan wisata Syariah yang berkelanjutan akan dapat memberikan kontribusi ekonomi yang cukup signifikan bagi seluruh pelaku yang terlibat didalamnya. 
Indonesia memiliki potensi besar untuk mengembangkan wisata halal yang harus di dukung dengan penerapan teknologi informasi. Perusahaan Google telah meluncurkan aplikasi Google Maps untuk mencari lokasi tempat yang ingin di kunjungi akan namun belum spesifik tentang wisata halal yang di butuhkan oleh para wisatawan. Penelitian ini berorientasi pada pembuatan aplikasi wisata halal berbasis android yang dapat memudahkan para wisatawan untuk mengakses informasi wisata halal. Metode yang di gunakan dalam penelitian ini adalah Geolocation dan Haversine Formula.

Geolocation adalah sebuah cara untuk mengetahui suatu lokasi di dunia. Terdapat beberapa metode untuk menemukan lokasi, yaitu dengan IP address, sambungan wireless atau BTS, dan dedicated GPS atau embeded GPS pada telepon seluler. Geolocation menggunakan fasilitas LBS dari Google Maps yang dapat digunakan dengan Google Maps API (Arief dkk: 2012).

Haversine formula digunakan untuk mengetahui dan menghitung jarak antara 2 titik dengan meperhitungkan derajat kelengkungan bumi sehingga hasil yang di peroleh lebih akukurat karna mampu menampilkan bentuk bidang tanah. Sehinga diperoleh jalur yang harus di tempuh dari lokasi user menuju tempat wisata halal yang akan di kunjungi menggunakan bantuan dari Google Direction Service setelah koordinat user dan objek wisata diketahui. Teknologi pendataan informasi wisata halal menggunakan web service REST API with JSON sehingga database bisa terintegrasi dengan sistem informasi pariwisata yang ada di dinas pariwisata.

Konsep Halal juga telah di kembangkan di negara Jepang sebagai Halal Tourism in Japan seperti pada penelitian (Shin Yasuda 2017) dengan judul Managing Halal Knowledge in Japan Developing Knowledge Platforms for Halal Tourism in Japan. Hasil penelitian ini menunjukan bahwa sertifikasi halal sangat berpengaruh terhadap industri pariwisata di jepang.Sehingga di bentuklah badan sertifikasi halal di Jepang untuk memberikan sertifikasi halal dan kebijakan terkait dengan Halal Tourism.

Peneliti mitra (Zainal A Hasibuan, Harry B Santoso 2005) dengan judulStandardisasi aplikasi e-government untuk instansi pemerintah. Telah melakukan penelitian tentang standarisasi aplikasie-government dengan menggunakan kajian Kerangka Teknologi Informasi Nasional. Kajian tersebut sangat perlu bagi penelitian ini agar bisa membuat aplikasi yang terintegrasi dengan aplikasi pemerintahan.

Penelitian (Nuradiansyah \& Budi, 2015) dengan judul "Development of Geospatial Dashboard with Analytic Hierarchy Processing for the Expansion of Branch Office Location". Telah melakukan penelitian tentang Dashboard Geospsial dengan teknologi semantik web mengunakan metode Analytic Hierarchy Processing (AHP). Untuk membuat visualisasi peta dan rekomendasi pembangunan wilayah pada cabang perusahaan menggunakan kreteria lokasi dan jarak. Sehingga pada penelitian ini mencoba untuk membuat visualisasi peta Geospasial pada aplikasi android dengan rekomendasi rute 
lokasi terdekat yang terintegrasi dengan sistem informasi pariwisata di Kabupaten Jombang.

\section{TINJAUAN PUSTAKA}

\section{Aplikasi}

Pengertian aplikasi secara umum adalah alat terapan yang difungsikan secara khusus dan terpadu sesuai kemampuan yang dimilikinya aplikasi merupakan suatu perangkat komputer yang siap pakai bagi user. Pengertian aplikasi menurut Jogiyanto dalam (Mulyanto, 2009) adalah penggunaan dalam suatu komputer, instruksi (instruction) atau pernyataan (statement) yang disusun sedemikian rupa sehingga komputer dapat memproses input menjadi output.

Beberapa aplikasi yang digabung bersama menjadi suatu paket kadang disebut sebagai suatu paket atau suite aplikasi (application suite). Contohnya adalah Microsoft Office dan OpenOffice.org, Bahasa Pemrograman yang menggabungkan suatu aplikasi pengolah kata, lembar kerja, serta beberapa aplikasi lainnya. Aplikasi-aplikasi dalam suatu paket biasanya memiliki antarmuka pengguna yang memiliki kesamaan sehingga memudahkan pengguna untuk mempelajari dan menggunakan tiap aplikasi

Berdasarkan jenisnya, aplikasi komputer dapat dibagi menjadi beberapa kategori, yaitu enterprise, enterprise-SupPort, individual worker, aplikasi akses konten, aplikasi pendidikan, aplikasi simulasi, pengembangan media dan aplikasi mekanika dan produk.

Enterprise digunakan untuk organisasi yang cukup besar dengan maksud menghubungkan aliran data dan kebutuhan informasi antar bagian, contoh: IT helpdesk, travel management dan lain-lain. Sedangkan Enterprise-SupPort digunakan sebagai aplikasi pendukung dari enterprise, contohnya: database management, email server dan networking system (Purbasari, Kahfi, \& Yunus, 2013).

Individual Worker digunakan sebagai aplikasi yang biasa digunakan untuk mengolah/edit data oleh tiap individu. Contoh Ms.Office, Photoshop, Acrobat Reader dan lain-lain. Aplikasi Akses Konten adalah aplikasi yang digunakan oleh individu (hanya) untuk mengakses konten tanpa kemampuan untuk mengolah atau mengedit datanya melainkan hanya melakukan kustomisasi terbatas contoh games, media player, web browser.

Aplikasi Pendidikan adalah biasanya berbentuk simulasi dan mengandung konten yang spesifik untuk pembelajaran. Aplikasi Simulasi biasa digunakan untuk melakukan simulasi penelitian, pengembangan dan lain-lain contoh Simulasi pengaturan lampu lalu lintas dan aplikasi pengembangan media berfungsi untuk mengolah/mengembangkan media biasanya untuk kepentingan komersial, hiburan dan pendidikan contoh digital animation software, audio video converter dan lain-lain. Aplikasi Mekanika dan Produk dibuat sebagai pelaksana/pengolah data yang spesifik 
untuk kebutuhan tertentu. Contoh Computer Aided Design (CAD), Computer Aided Engineering (CAE), SPSS dan lain-lain.

\section{Wisata Halal}

Menurut Kemenpar (Kemenpar, 2013) Istilah wisata halal baru mulai dikenal sejak 2015 ketika sebuah event World Halal Tourism Summit (WHTS) digelar di Abu Dhabi, UAE. Sebelumnya dunia pariwisata hanya mengenal sebagai Moslem tour atau semisalnya. Dalam event ini WHTS berusaha menyadarkan bahwa pangsa pasar dari wisata halal amatlah besar dan perlu untuk terus dikembangkan.

Terminologi wisata halal di beberapa negara ada yang menggunakan istilah seperti Islamic tourism, halal tourism, halal travel, halal lifestyle, ataupun as moslem friendly destination. Dari sisi industri, wisata halal merupakan suatu produk pelengkap dan tidak menghilangkan jenis pariwisata konvensional. Sebagai cara baru untuk mengembangkan pariwisata Indonesia yang menjunjung tinggi budaya dan nilai-nilai Islami tanpa menghilangkan keunikan dan orisinalitas daerah (Kemenpar, 2016).

Kemenpar (2016) mendefinisikan pariwisata halal merupakan sebuah kegiatan yang didukung oleh berbagai fasilitas serta layanan yang disediakan masyarakat, pengusaha, pemerintah, dan pemerintah daerah yang memenuhi ketentuan syariah. Menurut Adinugraha dkk (2018) pariwisata halal dimanfaatkan oleh banyak orang karena karakteristik produk dan jasanya yang bersifat universal. Produk dan jasa wisata, objek wisata, dan tujuan wisata dalam pariwisata halal adalah sama dengan produk, jasa, objek dan tujuan pariwisata pada umumnya selama tidak bertentangan dengan nilai-nilai dan etika syariah. Jadi pariwisata halal tidak terbatas hanya pada wisata religi. Konsep wisata Syariah adalah sebuah proses pengintegrasian nilai-nilai keisalaman kedalam seluruh aspek kegiatan wisata. Nilai syariat Islam sebagai suatu kepercayaan dan keyakinan yang dianut umat Muslim menjadi acuan dasar dalam membangun kegiatan pariwisata. Wisata Syariah mempertimbangkan nilai-nilai dasar umat Muslim didalam penyajiannya mulai dari akomodasi, restaurant, hingga aktifitas wisata yang selalu mengacu kepada norma-norma keisalaman.

Menurut Muhajirin (2018), definisi wisata halal lebih luas dari wisata religi yaitu wisata yang didasarkan pada nilai-nilai syariah Islam. Seperti yang dianjurkan oleh World Tourism Organization (WTO), konsumen wisata halal bukan hanya umat Muslim tetapi juga non Muslim yang ingin menikmati kearifan lokal. Pemilik jaringan Hotel Sofyan menjelaskan kriteria umum wisata halal ialah: 1) Memiliki orientasi kepada kemaslahatan umum. 2) Memiliki orientasi pencerahan, penyegaran, dan ketenangan. 3) Menghindari kemusyrikan dan khurafat. 4) Bebas dari maksiat. 5) Menjaga keamanan dan kenyamanan. 6) Menjaga kelestarian lingkungan. 7) Menghormati nilai-nilai sosial budaya dan kearifan lokal. 
Fundamental dari wisata Syariah tentunya adalah pemahaman makna halal disegala aspek kegiatan wisata mulai dari hotel, sarana transportasi, sarana makanan dan minuman, sistem keuangan, hingga fasilitas dan penyedia jasa wisata itu sendiri . Sebagai contoh hotel Syariah tidak akan menerima pasangan tamu yang akan menginap jika tamu tersebut merupakan pasangan yang bukan muhrimnya (tidak dapat menunjukkan surat nikah) selain itu hotel yang mengusung konsep Syariah tentunya tidak akan menjual minuman beralkohol serta makanan yang mengandung daging babi yang diharamkan didalam Islam.

\section{METODE PENELITIAN}

Pendekatan yang digunakan dalam penelitian ini adalah rancang bangun, yaitu melakukan perancangan dan pembangunan sistem dengan menggunakan teknologi berbasis Android, perancangan dan pembangunan sistem ini didasarkan pada data yang diperoleh dari kebutuhan obyek penelitian/ narasumber yang dianalisis dengan teori yang relevan.

Metode perancangan dan pengembangan sistem adalah User Centered Design (UCD) merupakan paradigma baru dalam pengembangan sistem berbasis web. User centered design (UCD) juga sering disebut sebagai human centered design. Menurut ISO 13407, buman centered design adalah sebuah pendekatan pengembangan sistem interaktif yang secara khusus fokus untuk membuat sebuah sistem berguna. Definisi lainnya menurut (Henry, S. L. 2004), user centered design adalah sebuah proses desain interfaceyang fokus terhadap tujuan kegunaan, karakteristik pengguna, lingkungan, tugas, dan alur kerja di dalam desainnya. UCD adalah sebuah proses iterative (berulang-ulang), dimana desain dan evaluasi dibangun dari langkah awal hingga implementasi secara terus menerus. Prinsip dasar pada metode UCD adalah fokus pada pengguna, perancangan terintegrasi, dari awal berlanjut pada pengujian pengguna dan perancangan interaktif.

Secara informal, usability dapat diartikan sebagai tingkat kemudahan suatu produk untuk digunakan. Berdasarkan ISO usability didefinisikan sebagai "...the effectiveness, efficiency, and satisfaction with which specified users can achieve specified goals in particular environments" (ISO DIS 9241-11). Menurut ahli Usability (Nielsen Jacob 1994) kriteria - kriteria web usability adalah sebagai berikut learnability, efficiency, memorability, errors dan satisfaction:

Learnability adalah kriteria yang mengukur tingkat kemudahan suatu situs untuk dipelajari dan digunakan, khususnya bagi pengguna yang baru pertama kali melihat dan menjelajahi situs tersebut. Efficiency adalah kriteria yang mengukur tingkat performansi pengguna ketika menggunakan situs.

Memorability adalah kriteria kualitatif yang dapat dilihat melalui kemudahan penggunadalam menggunakan lagi produk (situs) setelah beberapa saat tidak mengunjungi situs. Errors adalah kriteria kuantitatif pada web usability, errors menilai 
situs melalui banyaknya kesalahan yang dilakukan oleh pengguna ketika melakukan tugas skenario yang diberikan.

Satisfaction adalah pengukuran kualitatif yang dirasakan atau juga ditunjukkan oleh pengguna, ketika sistem atau situs yang digunakan menyenangkan dan juga mudah dipakai akan memberikan kenyamanan kepada pengguna atau juga memberikan rasa puas ketika pengguna dapat menyelesaikan tugas yang diberikan dengan baik.

\section{Gambar 1}

\section{Alur Pembuatan Aplikasi Sistem Halal}

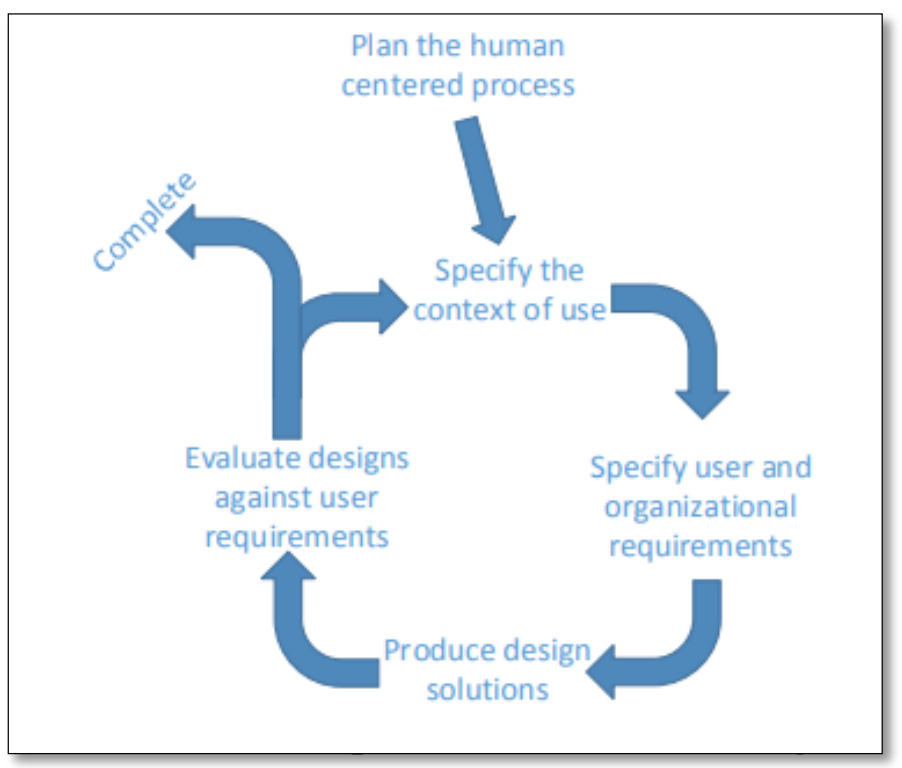

Keterangan Gambar:

1. Specify the context of use Mengidentifikasi orang yang akan menggunakan sistem. Ini akan menjelaskan untuk apa dan dalam kondisi seperti apa, mereka akan menggunakan sistem.

2. Specify User and Organizational Requirements Mengidentifikasi kebutuhan pengguna dan kebutuhan organisasi.

3. Produce Design Solutions Membangun desain sebagai solusi dari sistem yang sedang dianalisis.

4. Evaluate Design Melakukan evaluasi terhadap desain yang dilakukan pada tahap sebelumnya.

\section{HASIL DAN PEMBAHASAN}

Desain Arsitektur Teknologi perancangan aplikasi wisata halal berbasis android dengan metode geolocation adalah sebagai berikut:

Geolacation atau layanan berbasis lokasi adalah istilah umum yang digunakan untuk menggambarkan teknologi yang digunakan untuk menemukan lokasi perangkat yang digunakan untuk menemukan lokasi perangkat yang kita gunakan. Location Based Service (LBS) yaitu service yang berfungsi untuk mencari dengan teknologi 


\section{Mîmar Surnal \&konomi \& Q Quangan ఖslam \\ Dinar. Vol 6, No 2: Agustus 2019. 83-94 https://journal.trunojoyo.ac.id/dinar/index ISSN: 2460-9889 (Cetak) \\ DOI: https://doi.org/10.21107/dinar ISSN: 2580-3565 (Online)}

GPS dan Google's cell-based location. Maps dan layanan berbasis lokasi menggunakan lintang dan bujur untuk menentukan lokasi geografis, namun user membutuhkan alamat atau posisi realtime kita bukan nilai lintang dan bujur. Android menyediakan geocoder yang mengdukung forward dan reverse geocoding. Menggunakan geocoder, anda dapat mengonversi nilai lintang bujur menjadi alamat dunia nyata atau sebaliknya (Abidin, 2007).

Arsitektur sistem Geolacation ada pada gambar berikut :

\section{Gambar 2}

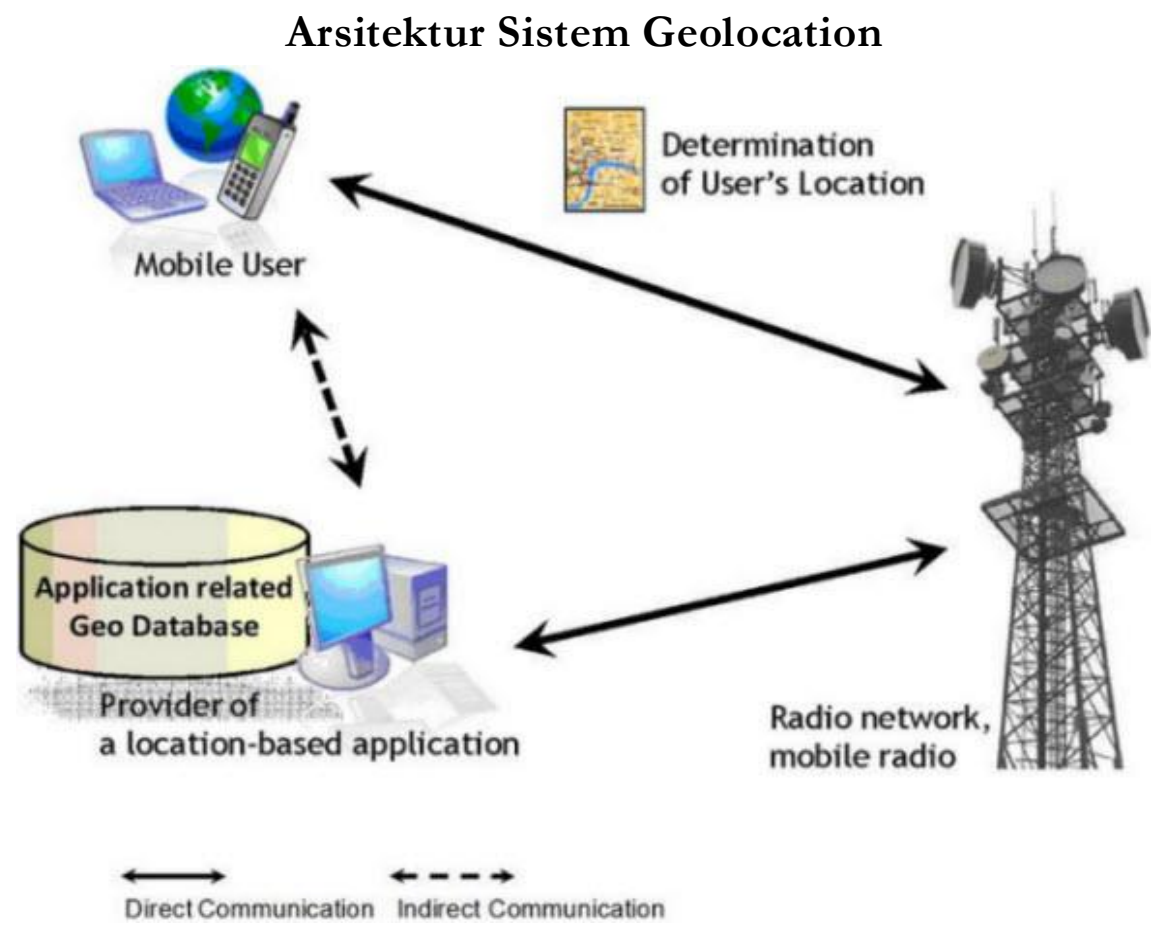

Penelitian Reza Pradana menerapkan metode geolocation untuk pencarian wisata kuliner berbasis mobile di kabupaten malang telah berhasil di terapkan. Dan memberikan hasil yang efektif untuk pencarian lokasi user/perangkat. Hanya saja terdapat perbedaan koordinat dengan lokasi wisata karna kondisi wilayah kabupaten malang adalah pegunungan. Untuk itu diperlukan penambahan meode Haversine Formula. Agar mampu memberikan hasil perhitungan yang lebih akurat.

Teorema Haversine Formula adalah sebuah persamaan yang penting dalam bidang navigasi, untuk mencari jarak busur antara dua titik pada bola dari longitude dan latitude. Ini merupakan bentuk persamaan khusus dari trigonometri bola, law of haversines, mencari hubungan sisi dan sudut pada segitiga dalam bidang bola. Formula ini pertama kali ditemukan oleh Jamez Andrew di tahun 1805, dan digunakan pertama kali oleh Josef de Mendoza y Ríos di tahun 1801. Istilah haversine ini sendiri diciptakan pada tahun 1835 oleh Prof. James Inman. Josef de Mendoza y 
Ríos menggunakan haversine pertama kali dalam penelitiannya tentang "Masalah Utama Astronomi digunakan untuk menemukan jarak antar bintang.

Hukum Haversin di jelaskan pada gambar berikut:

\section{Gambar 3}

\section{Hukum Haversin}

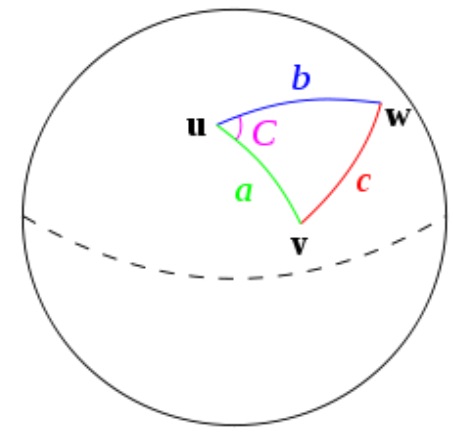

Dalam sebuah unit bola, sebah segitiga pada permukaan bola didefinisikan oleh lingkaran besar yang menghubungkan tiga titik yaitu u, v, dan w pada bola. Jika panjang dari tiga sisi adalah (dari u ke v), b (dari u ke w), dan c (dari v ke w), dan sudut sudut yang berlawanan dari c adalah $\mathrm{C}$, maka hukum haversin es adalah sebagai berikut :

$$
\text { haversin }(c)=\text { haversin }(a-b)+\sin (a) \sin (b) \text { haversin }(C)
$$

Karena ini adalah sebuah unit lingkaran bola, sehingga panjang a, b, dan c hanya sama dengan sudut (dalam radian) berdasarkan pada sisi-sisi dari pusat lingkaran bola (pada lingkaran tak penuh, masing-masing panjang busur sama dengan sudut pusat dikalikan dengan jari-jari bola).

Untuk mendapatkan rumus haversine dari bagian sebelumnya, secara sederhana kita mempertimbangkan sebuah kasus khusus di mana u adalah kutub utara, sementara $\mathrm{v}$ dan $\mathrm{w}$ adalah dua titik yang dipisahkan oleh $\mathrm{d}$ yang akan ditentukan.

Dalam hal ini, a dan b adalah $\pi / 2-\varphi 1,2$ (yaitu, $90^{\circ}$ - lintang), $C$ adalah selisih bujur $\Delta \lambda$, dan c adalah $\mathrm{d} / \mathrm{R}$ yang diinginkan. Dimana $\sin (\pi / 2-\varphi)=\cos (\varphi)$, maka rumus haversine dapat segera mengikuti.Untuk menurunkan hukum haversines, saat dimulai dengan hukum bola cosinus

Perancangan aplikasi wisata halal berbasis android dengan metode geolocation memiliki tiga kebutuhan fungsional utama dari aplikasi ini, yaitu: pengguna dapat melihat informasi detail wisata kuliner, pengguna dapat mencari objek lain dari objek wisata kuliner pada jarak tertentu dan pengguna dapat melihat rute menuju objek wisata kuliner dari posisi pengguna. 
Gambar 4

\section{Perancangan Alur Aplikasi}

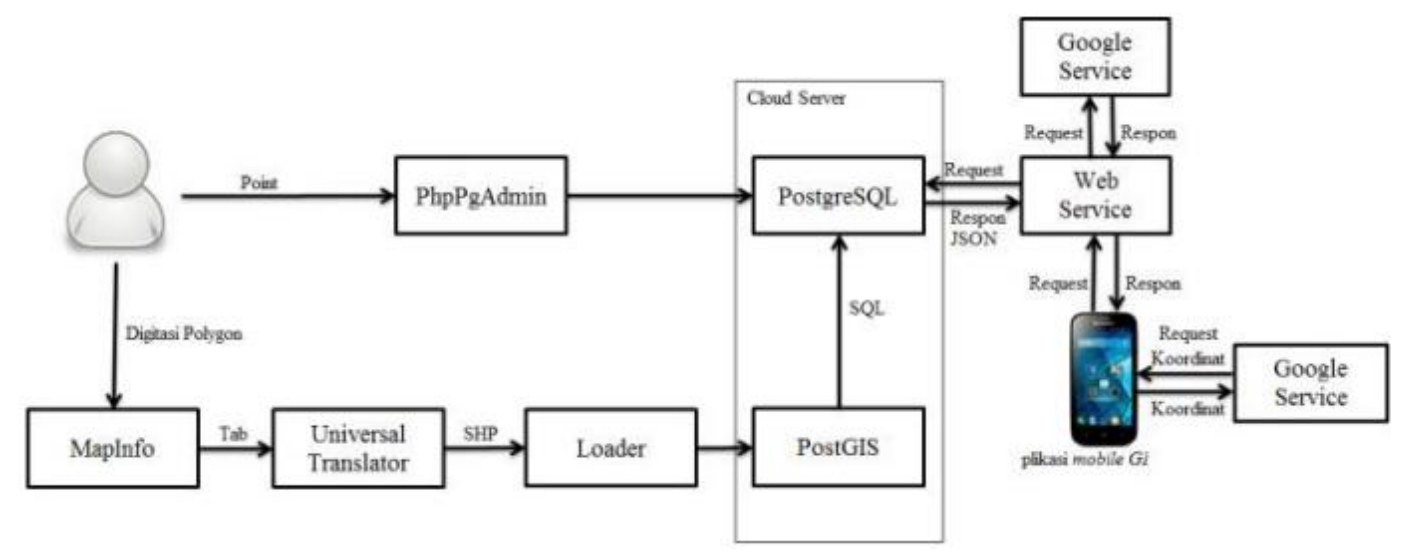

Ada dua tipe data spasial yang digunakan dalam membangun aplikasi wisata kuliner ini, yaitu: 1) Point, berfungsi untuk menyimpan titik koordinat wisata kuliner dan titik koordinat pengguna dan 2) Polygon, yang berfungsi untuk menyimpan data batas koordinat wilayah Kabupaten Jombang. Use case aplikasi wisata kuliner dapat dilihat pada Gambar 6 di atas.

\section{Gambar 6}

\section{Use Case Aplikasi Wisata Halal Berbsasis Android}

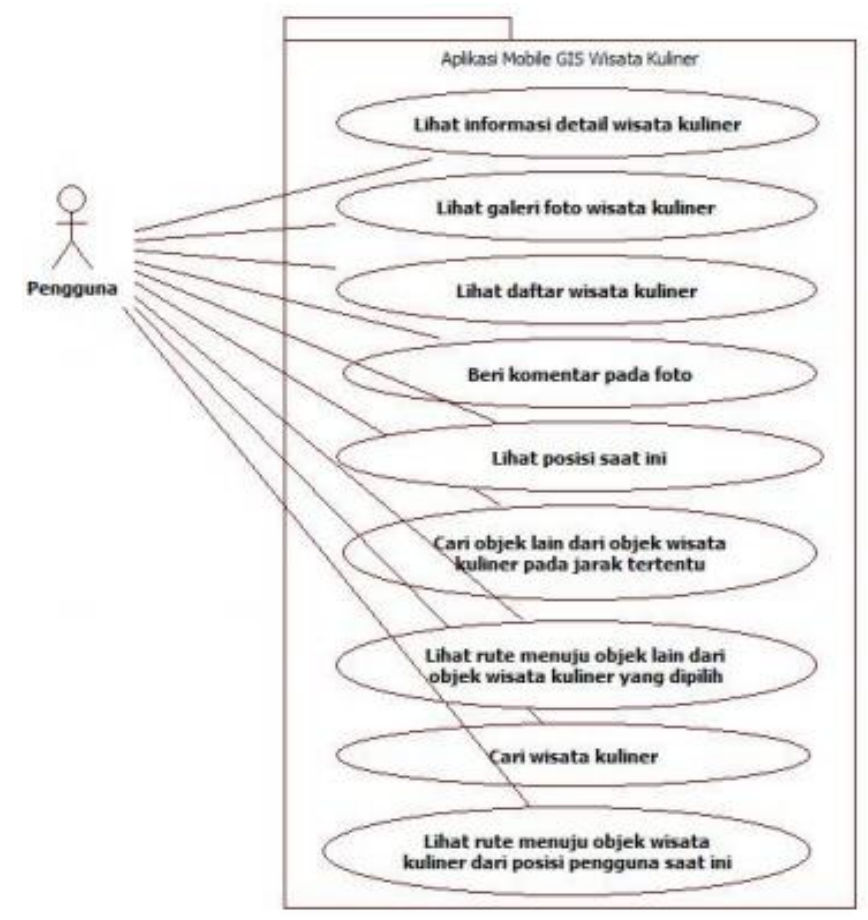

\section{KESIMPULAN}

Perancangan aplikasi wisata halal berbasis android dengan metode geolocation di Kabupaten Jombang telah berhasil dibangun. Aplikasi wisata kuliner ini dibangun 
melalui beberapa tahap, yaitu tahap analisis sistem, tahap perancangan sistem. Metode yang di gunakan adalah User Centered Design (UCD), yang fokus pada pengguna dan dapat terintegrasi dengan platform perangkat sistem informasi dinas pariwisata.

\section{DAFTAR PUSTAKA}

Abidin, H. (2007). Penentuan Posisi dengan GPS dan Aplikasinya. In (3rd ed.). Jakarta, Indonesia: PT. Pradnya Paramita.

Adinugraha, H. H., Sartika, M., \& Kadarningsih, A. (2018). Desa Wisata Halal : Konsep Dan Implementasinya Di Indonesia. Human Falah.

Arief, A., Widyawan, \& Sunafri Hantono, B. (2012). Rancang Bangun Sistem Rekomendasi Pariwisata Mobile dengan Menggunakan Metode Collaborative Filtering dan Location Based Filtering. JNTETI.

Google. 2018. Developers Google Maps API Android V2 Developer Guide. Diakses pada 4 Agustus2018, dari https://developers.google.com/maps/documentation/android

HB Santoso, M Schrepp, RYK Isal, AY Utomo, B Priyogi,. 2016 User Experience Questionnaire: Development of an Indonesian Version and Its Usage for Product Evaluation The Journal of Educators Online JEO, Vol 13 pp. 58-79

Harry B Santoso,Zainal A Hasibuan, 2015 Prosiding Konferensi Nasional Teknologi Informasi dan Komunikasi Indonesia ITB (hal. 42-48). Bandung: ITB

Henry, S. L. (2004). Notes on User-Centered Design Process (UCD). Diakses pada 5 Agustus 2018 dari http://www.w3.org/WAI/EO/2003/ucd

Kemenpar. (2013). Lampiran I Peraturan Menteri Pariwisata Dan Ekonomi Kreatif Republik Indonesia Nomor Pm.53/Hm.001/Mpek/2013 Tentang Standar Usaha Hotel. Www.Kemenpar.Go.Id.

Kemenpar. (2016). Pembangunan Destinasi Pariwisata Prioritas 2016 - 2019. Rapat Koordinasi Nasional Kementerian Pariwisata "Akselerasi Pembangunan Kepariwisataan Dalam Rangka Pencapaian Target 12 Juta Wisman Dan 260 Juta Wisnus 2016."

Muhajirin, M. (2018). Pariwisata Dalam Tinjauan Ekonomi Syariah. Al-Mashlahah: Jurnal Hukum Islam Dan Pranata Sosial. https:/ / doi.org/10.30868/am.v6i01.241

Mulyanto, A. (2009). Sistem Informasi Konsep dan Aplikasi. Yogyakarta: Pustaka Pelajar. https://doi.org/10.1007/s13398-014-0173-7.2

Nuradiansyah, A., \& Budi, I. (2015). Development of geospatial dashboard with analytic hierarchy processing for the expansion of branch office location. CEUR Workshop Proceedings.

Purbasari, R. julia, Kahfi, M. S., \& Yunus, M. (2013). Pengembangan Aplikasi Android Sebagai Media Pembelajaran Matematika Pada Materi Dimensi Tiga Untuk Siswa SMA Kelas X. Jurnal Online Universitas Negeri Malang. 
Salindal, N. A. (2019). Halal certification compliance and its effects on companies' innovative and market performance. Journal of Islamic Marketing. https://doi.org/10.1108/JIMA-04-2018-0080 